\title{
Benign Ito Cell Tumor
}

National Cancer Institute

\section{Source}

National Cancer Institute. Benign Ito Cell Tumor. NCI Thesaurus. Code C80351.

A benign tumor of the liver composed of hepatic stellate cells. 